\title{
ANALISIS PRICE BOOK VALUE, EARNING GROWTH, RETURN ON ASSETS, DAN PRICE EARNING RATIO PADA PERUSAHAAN PEMBIAYAAN DI INDONESIA
}

\author{
Septianty Intan Kusuma Pertiwi \\ Program Studi Akuntansi Fakultas Ekonomi Universitas BSI \\ septiantypertiwi@gmail.com \\ Catur Martian Fajar \\ Program Studi Akuntansi Fakultas Ekonomi Universitas BSI \\ catur.cmf@bsi.ac.id
}

\begin{abstract}
ABSTRAK
Penilaian tingkat kinerja perusahaan pembiayaan merupakan kepentingan bagi semua pihak yang terkait (stake holder), baik pemegang saham dan pengelola perusahaan pembiayaan, pihak pengguna jasa perusahaan pembiayaan baik supplier, kreditur, maupun nasabah perusahaan pembiayaan (lessee, client, consumer, maupun card holder), dan Otoritas Jasa Keuangan sebagai pembina dan pengawas perusahaan pembiayaan. Penelitian ini bertujuan untuk menguji adanya pengaruh price book value, earning growth, dan return on assets terhadap price earning ratio pada perusahaan pembiayaan yang terdaftar di bursa efek Indonesia. Teknik analisis data menggunakan metode deskriptif verifikatif. Hasil penelitian menunjukkan bahwa price book value mempunyai pengaruh positif dan signifikan terhadap price earning ratio, earning growth mempunyai pengaruh negatif dan tidak signifikan terhadap price earning ratio dan return on assets mempunyai pengaruh positif dan tidak signifikan terhadap price earning ratio. Secara simultan price book value, earning growth dan return on assets berpengaruh signifikan terhadap price earning ratio pada perusahaan pembiayaan.
\end{abstract}

Kata Kunci:

price book value, earning growth, return on assets, price earning ratio

\begin{abstract}
ABSTRACK
Valuation of the performance level of finance companies are benefit to all stakeholders, both shareholders and finance companies' manager, the finance companies service clients, suppliers, creditors, and the finance company customers (lessee, client, consumer, or card holder), and the Financial Services Authority as the supervisor and the adviser of the finance company. This study aims to examine the influence of price book value, earnings growth, and return on assets towards price earnings ratio in finance companies listed on the Indonesian stock exchange. Data analysis technique using descriptive method verification. The result of the research shows that price book value has a positive and significant influence on price earning ratio, earning growth has a negative and insignificant effect on price earning ratio and return on assets has a positive and insignificant effect on price earnings ratio. Simultaneously price book value, earnings growth and return on assets have a significant effect on price earning ratio in finance company.
\end{abstract}

Keywords:

Price Book Value, Earning Growth, Return On Assets, Price Earning Ratio 


\section{PENDAHULUAN}

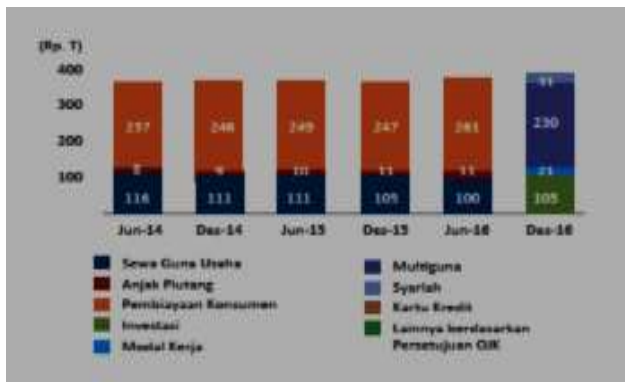

Gambar 1.

Pembiayaan perusahaan pembiayaan per jenis usaha

Sumber: Otoritas jasa keuangan, 2017

Pada bulan Desember 2016, industri

keuangan non bank (IKNB) khususnya perusahaan pembiayaan (PP) menunjukkan kinerja yang positif jika dibandingkan dengan bulan Juni 2016, yang sebelumnya telah mengalami penurunan sejak bulan Desember 2013 (Agus, 2017). Penurunan pertumbuhan tersebut terjadi karena terjadinya perlambatan ekonomi yang disertai dengan pelemahan daya beli masyarakat sehingga mengakibatkan volume pembiayaan turun dan berimplikasi pada aset menurunnya kinerja perusahaan pembiayaan (Agus, 2016). Kinerja perusahaan pembiayaan selama bulan Desember 2016 mengalami perbaikan baik dari sisi pembiayaan maupun pendanaan meski masih menyisakan permasalahan peningkatan non perfoming finance dibandingkan dengan bulan Juni 2016.

Berdasarkan gambar 1, dapat diketahui selama bulan Desember 2016 pertumbuhan pembiayaan pada perusahaan pembiayaan meningkat sebesar 6,67\%. Dilihat berdasarkan jenisnya, pembiayaan didominasi oleh pembiayaan multiguna dengan proporsi mencapai 59,39\% dari total pembiayaan diikuti oleh pembiayaan investasi sebesar $27,09 \%$, pembiayaan berdasarkan prinsip syariah sebesar $8,09 \%$ dan pembiayaan modal kerja 5,41\% (Agus, 2017).

Penilaian kinerja perusahaan merupakan kepentingan bagi semua pihak yang terkait (stakeholder), seperti pemegang saham dan pengelola perusahaan pembiayaan, pihak pengguna jasa perusahaan pembiayaan baik supplier, kreditur maupun nasabah perusahaan pembiayaan (lessee, client, consumer, maupun card holder), serta Otoritas Jasa Keuangan sebagai pembina dan pengawas perusahaan pembiayaan. Berdasarkan pasal 5 ayat 1 Peraturan OJK No.29/PJOK.05/2014 tentang Penyelenggaraan Usaha Perusahaan Pembiayaan, yang menyatakan bahwa perusahaan pembiayaaan wajib setiap waktu memenuhi persyaratan tingkat kesehatan keuangan dengan kondisi minimum sehat (Wijoyo, 2016).

Ohlson menyatakan, "penilaian kinerja keuangan membantu pihak manajemen dalam 
menilai keputusan investasi dan kinerja

perusahaan serta dapat memberikan peringatan mengenai perlambatan kinerja keuangan perusahaan" (Martani \& Khairurizka, 2009).

"Pertumbuhan kinerja saham menjadi daya tarik bagi investor atau individu yang terlibat langsung atau tidak langsung dengan aktivitas dan kinerja pasar" (Mahmood \& Fatah, 2009). Capital gain yang dihasilkan oleh kinerja perusahaan diperhatikan investor dengan menilai pertumbuhan kinerja pasar saham perusahaan yang terdaftar di bursa saham (Khan, 2009).

Price Earning Ratio (PER) merupakan rasio yang dapat mengukur kinerja saham perusahaan dengan membandingkan harga pasar saham dengan laba per lembar saham (Arisona, 2013). Poernamawatie mengemukakan bahwa, "Pada prinsipnya PER memberikan indikasi mengenai jangka waktu yang diperlukan untuk mengembalikan dana pada tingkat harga saham dan keuntungan pada suatu periode tertentu" (Viandita, Suhadak, \& Husaini, 2013).Berikut merupakan data mengenai rata-rata price earning ratio pada perusahaan pembiayaan yang tedaftar di Bursa Efek Indonesia.

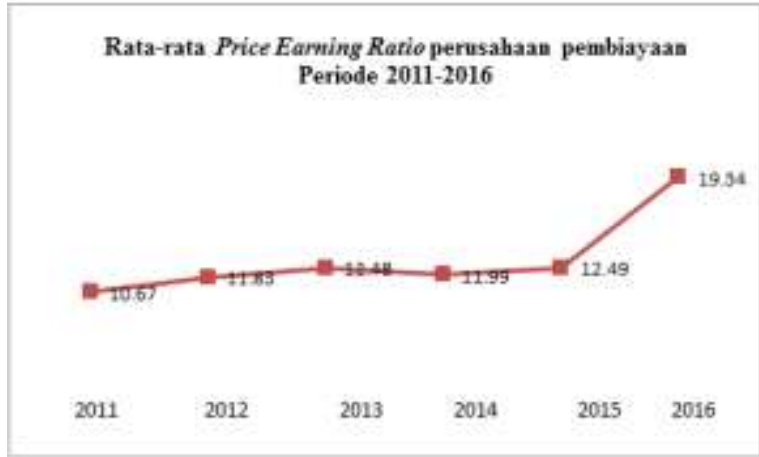

Gambar 2.

Rata-rata price earning ratio perusahaan pembiayaaan

Sumber: Laporan keuangan perusahaan pembiayaan

Berdasarkan Gambar 2, dapat diketahui rata-rata price earning ratio perusahaan pembiayaan pada tahun 2011-2016 dalam kondisi stabil dan cenderung meningkat, dimana rata-rata price earning ratio yang paling tinggi terjadi pada tahun 2016 yaitu sebesar 19.34 kali berarti bahwa investasi yang ditanamkan oleh investor akan kembali dalam kurun waktu 19 tahun dan yang paling rendah tahun 2011 yaitu sebesar 10.67 kali berarti bahwa investasi yang ditanamkan oleh investor akan kembali dalam kurun waktu 11 tahun.

Pertumbuhan price earning ratio yang rendah akan menurunkan minat investor terhadap harga saham perusahaan, namun perlu diingat pula bahwa price earning ratio yang rendah mempunyai potensi untuk meningkat, sehingga investor tidak hanya terpaku pada price earning ratio yang tinggi saja. Price 
earning ratio yang tinggi belum tentu mencerminkan kinerja yang baik, karena price earning ratio yang tinggi bisa saja disebabkan oleh turunnya rata-rata pertumbuhan laba perusahaan. "Faktor-faktor yang mempengaruhi Price earning ratio adalah price book value, dividend payout ratio, earning growth, return on equity, debt to equity ratio, serta ukuran perusahaan" (Arisona, 2013).

Penilaian terhadap Price Book Value (PBV) digunakan untuk melihat kewajaran harga saham. PBV yang rendah menunjukkan harga saham perusahaan yang rendah. "Posisi harga saham berada di bawah book value, maka mengakibatkan kecenderungan harga saham perusahaan menuju ke keseimbangan minimal sama dengan nilai bukunya" (Sumampow \& Murni, 2016).

Perusahaan yang berkinerja baik biasanya memiliki rasio PBV di atas satu (PBV>1). "Semakin tinggi price to book value, semakin baik pasar memandang perusahaan dan prospeknya. Hal ini berarti semakin berhasil perusahaan menciptakan nilai bagi pemegang saham” (Marlina, 2013)

Hal ini menunjukkan bahwa nilai pasar saham lebih besar daripada nilai bukunya. Berikut merupakan data mengenai rata-rata

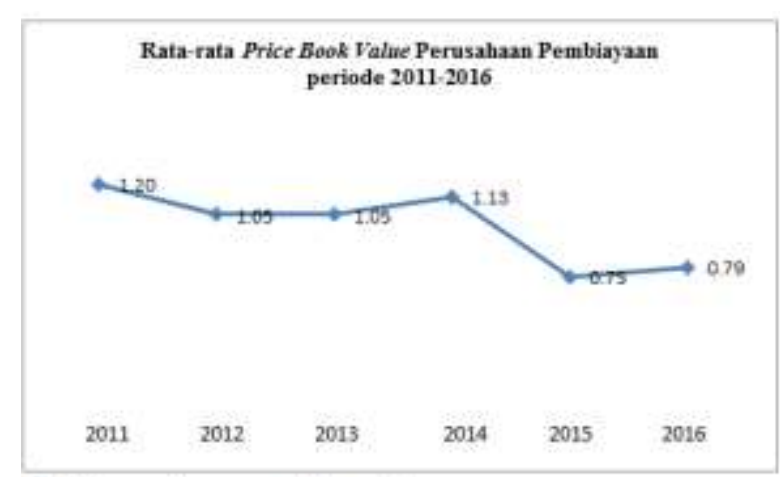

Gambar 3.

Rata-rata price book value perusahaan pembiayaan

Sumber: Laporan keuangan perusahaan pembiayaan price book value perusahaan pembiayaan yang terdaftar di Bursa Efek Indonesia.

Berdasarkan Gambar 3. dapat diketahui rata-rata price book value perusahaan pembiayaan pada tahun 2011-2016 mengalami fluktuasi dan cenderung mengalami penurunan, di mana rata-rata price book value yang paling tinggi terjadi pada tahun 2011 sebesar 1.20 kali berarti nilai pasar saham lebih besar daripada nilai bukunya dan yang paling rendah pada tahun 2015 yaitu sebesar 0.75 kali berarti nilai pasar saham lebih kecil daripada nilai bukunya. Penelitian yang dilakukan oleh Aji dan Pangestuti menemukan adanya pengaruh 
signifikan antara PBV terhadap PER (Aji \& Irene Rini Demi Pangestuti, 2012).

"Pertumbuhan perusahaan adalah salah satu tujuan yang diharapkan oleh pihak internal dan eksternal perusahaan karena akan membawa pengaruh baik bagi perusahaan dan pihak yang memiliki minat di perusahaan seperti investor, kreditor dan pemegang saham" (Rasyid, 2015). Pertumbuhan perusahaan dapat dinilai dari pertumbuhan laba yang meningkat. Pertumbuhan laba menunjukkan kemampuan perusahaan dalam meningkatkan earning per share perushaaan. Pertumbuhan laba per lembar saham dapat dilihat melalui prospek perusahaan di masa yang akan datang sehingga akan mempengaruhi keputusan investor dalam berinvetasi. Roswati menemukan pengaruh yang signifikan antara ROE, EPS, dan PBV terhadap harga saham perusahaan ritel (Martani \& Khairurizka, 2009). Berikut merupakan data mengenai rata-rata earning growth perusahaan pembiayaan yang terdaftar di Bursa Efek Indonesia"

Berdasarkan Gambar 4, dapat diketahui rata-rata earning growth yang terdapat di perusahaan pembiayaan pada tahun 2011-2016 mengalami fluktuasi, di mana rata-rata earning growth yang paling tinggi terjadi pada tahun

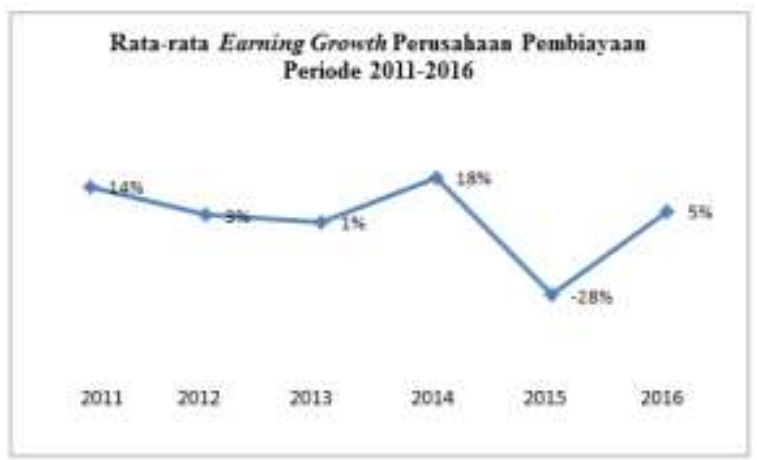

Gambar 4.

Rata-rata earning growth perusahaan pembiayaan

Sumber: Laporan keuangan perusahaan pembiayaan 2014 sebesar 18\% itu berarti kinerja keuangan perusahaannya baik sehingga pertumbuhan labanya tinggi dan yang paling rendah tahun 2015 yaitu sebesar -28\% itu berarti perusahaan pembiayaan menunjukkan kineja yang kurang baik sehingga pertumbuhan labanya rendah. Setiap perusahaan dapat memaksimalkan labanya apabila manajer keuangan dapat mengetahui seberapa besar faktor-faktor yang mempengaruhi tingkat profitabilitas perusahaan.

Menurut Kasmir (2015), rasio profitabilitas merupakan rasio untuk menilai kemampuan perusahaan dalam mencari keuntungan. Husnan menyatakan bahwa profitabilitas perusahaan adalah salah satu alternatif yang digunakan untuk menilai secara akurat sejauh mana tingkat pengembalian akan diperoleh dari kegiatan investasi (Rasyid, 2015). Profitabilitas dapat mencerminkan laba 
investasi keuangan, yang berarti bahwa profitabilitas akan mempengaruhi nilai perusahaan jika kemampuan perusahaan untuk menghasilkan laba meningkat karena harga saham juga akan meningkat (Rasyid, 2015).

Profitabiltas dapat diukur dengan return on assets (ROA). ROA mengukur kemampuan perusahaan menghasilkan laba bersih berdasarkan tingkat assets bentuk investasi atau aktiva tertentu. Tingkat return on assets perusahaan ditentukan oleh keputusan perusahaan dalam alokasi dana yang mereka miliki pada berbagai bentuk investasi dan tingkat efisiensi pengguna aktiva perusahaan. Semakin besar return on assets menunjukan kinerja yang semakin baik, karena tingkat pengembalian asset akan semakin besar, hal tersebut akan menarik minat investor yang berimplikasi terhadap meningkatnya harga saham perusahaan.

Gambar 5 merupakan data mengenai rata-rata return on assets perusahaan pembiayaan yang terdapat di Bursa Efek Indonesia.

Berdasarkan Gambar 5, dapat diketahui rata-rata return on assets perusahaan pembiayaaan pada tahun 2011-2016 cenderung menurun dan terjadi peningkatan pada tahun

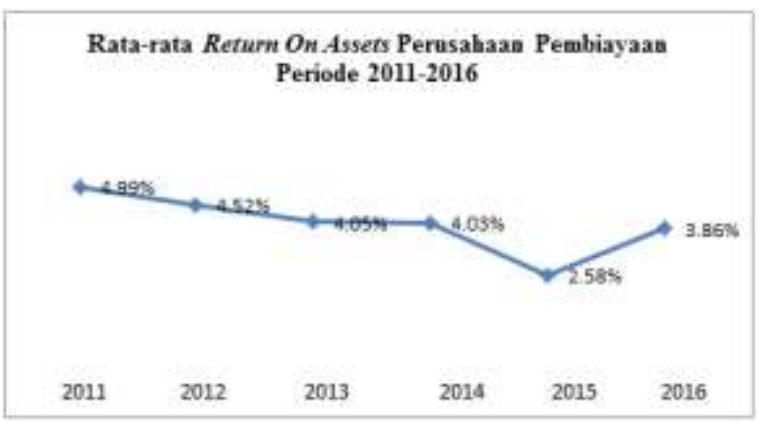

Gambar 5.

Rata-rata return on assets perusahaan pembiayaan

Sumber: laporan keuangan perusahaan pembiayaan 2016. Rata-rata return on assets yang paling tinggi terjadi pada tahun 2011 yaitu sebesar 4,99\% total aktiva lebih besar daripada laba perusahaan dan yang terendah terjadi pada tahun 2015 yaitu sebesar 2,58\% ini berarti laba perusahan lebih besar daripada total aktiva.

Berdasarkan permasalahan tersebut, maka tujuan penelitian ini adalah untuk menganalisis pengaruh price book value, earning growth, dan return on asset terhadap price earning ratio pada perusahaan pembiayaan.

\section{TINJAUAN TEORI}

\section{Price book value}

Price to Book Value (PBV) digunakan untuk mengukur kinerja harga pasar saham terhadap nilai bukunya. "Price to book value juga menunjukkan seberapa jauh perusahaan mampu menciptakan nilai perusahaan relatif 
terhadap jumlah modal yang diinvestasikan"

(Marlina, 2013).

Price book value dapat mempengaruhi harga saham, tingkat price book value dikatakan tinggi apabila harga saham lebih tinggi dibandingkan nilai bukunya (Rasyid, 2015). Rosenberg, et al. menyatakan bahwa, "saham yang memiliki rasio $\mathrm{PBV}$ rendah akan menghasilkan return yang secara signifikan lebih tinggi dibandingkan dengan saham yang memiliki rasio PBV tinggi” (Kurniawati, 2012)

Penelitian yang dilakukan oleh Utama dan Sentosa pada 128 perusahaan yang terdaftar di Bursa Efek Jakarta pada tahun 1995 membuktikan bahwa rasio PBV dapat digunakan dalam menetapkan strategi investasi karena dengan menggunakan rasio PBV, investor dapat memprediksi saham mana yang akan dinilai terlalu rendah dan dinilai terlalu tinggi (Martani \& Khairurizka, 2009).

\section{Earning growth}

Investor sangat perlu untuk mengetahui secara baik tingkat profitabilitas perusahaan agar investor dapat memperoleh tingkat pengembalian yang diharapkan di masa yang akan datang. Bagi investor, tingkat profitabilitas perusahaan biasanya diekspresikan sebagai laba per saham. Salah satu indikator yang digunakan oleh investor dalam menilai keberhasilan suatu perusahaan atau kinerja suatu perusahaan ditunjukan oleh besarnya earning per share (EPS) yang dapat dihasilkan oleh perusahaan tersebut. Earning growth menunjukkan prospek earning perusahaan di masa depan (Arisona, 2013).

"Pertumbuhan laba adalah perkembangan laba yang terjadi dalam suatu perusahaan dalam jangka waktu tertentu apakah laba meningkat atau sebaliknya menurun" (Rasyid, 2015).

"Pertumbuhan laba per lembar saham menunjukan sejauh mana perusahaan dapat meningkatkan kemampuannya untuk memperoleh pendapatan atau laba per lembar saham dibandingkan dengan total laba per saham secara keseluruhan” (Kasmir, 2012).

Pertumbuhan laba pada penelitian ini dinilai melalui pertumbuhan laba per lembar saham (earning per share). Pertumbuhan laba per lembar saham tersebut menunjukkan prospek perusahaan di masa yang akan datang sehingga akan mempengaruhi keputusan investor dalam berinvestasi. Tingkat pertumbuhan laba (earning growth) berpengaruh langsung terhadap price earning ratio. Bila harga saham mencerminkan 
kapitalisasi dari laba yang diharapkan di masa mendatang, maka peningkatan laba akan meningkatkan harga saham dan total kapitalisasi pasar. Bila investor yakin pertumbuhan laba ini baik, price earning ratio akan meningkat.

\section{Return on assets}

Atemnkeng \& Joseph menyatakan bahwa manfaat optimal bagi perusahaan adalah fungsi pengambilan keputusan dalam mengelola asset perusahaan yang ditentukan oleh beberapa faktor seperti tingkat pengembalian pengembalian aset, risiko kepemilikan aset dan ukuran portofolio (Setyawati et al. 2015). Return on asset adalah rasio yang menunjukan hasil (return) atas jumlah aktiva yang digunakan dalam perusahaan (Kasmir, 2012). Selain itu, return on assets memberikan ukuran yang lebih baik atas profitabilitas perusahaan karena menunjukan efektivitas manajemen dalam menggunakan aktiva untuk memperoleh pendapatan.

"Return on asset sering juga disebut sebagai return on investment, karena return on assets ini melihat sejauh mana investasi yang telah ditanamkan mampu memberikan pengembalian keuntungan sesuai dengan yang diharapkan dan investasi tersebut sebenarnya sama dengan aset perusahaan yang ditanamkan atau ditempatkan" (Fahmi, 2012).

Menurut (Kabajeh, AL Nu'aimat, \& Dahmash, 2012) “This ratio is calculated as net profit after tax divided by the total assets. This ratio measure for the operating efficiency for the company based on the firm's generated profits from its total assets". Dapat diartikan ROA dihitung dengan membandingkan laba bersih setelah pajak dibagi dengan total aset. Rasio ini merupakan ukuran tingkat efisiensi operasi perusahaan berdasarkan hasil keuntungan dari total aset.

Rasio return on assets ini sering digunakan pihak manajemen untuk mengukur kinerja keuangan perusahaan dan menilai kinerja operasional dalam memanfaatkan sumber daya yang dimiliki perusahaan, di samping perlu mempertimbangkan masalah pembiayaan terhadap aktiva tersebut. Return on assets menunjukkan seberapa banyak laba bersih yang bisa diperoleh dari seluruh kekayaan yang dimiliki perusahaan" (Putri \& Widodo, 2016). Bernardin (2016) juga menjelaskan Return on assets sebagai bagian dari rasio profitabilitas yang mengukur tingkat laba atas investasi dalam aktiva. 


\section{Price Earning Ratio}

Rasio yang sering digunakan dalam analisis saham adalah price earning ratio (PER). Pendekatan ini paling banyak digunakan oleh para pemodal dan analisis sekuritas. Sunariyah menyatakan bahwa pendekatan ini didasarkan hasil yang diharapkan pada perkiraan laba persaham yang akan datang, sehingga dapat diketahui berapa lama investasi saham akan kembali (Aji \& Irene Rini Demi Pangestuti, 2012).

Fahmi (2013), pengertian price earning ratio adalah "Perbandingan antara market price pershare (harga pasar per lembar saham) dengan earning price pershare (laba perlembar saham) terhadap kenaikan pertumbuhan laba yang diharapkan juga akan mengalami kenaikan”. Ang dan Bekaert mengemukakan bahwa PER dapat dijadikan sebagai indikator pertumbuhan dividend dan kemampuan menghitung return saham (Carlo, 2014).

Gill menyatakan bahwa, "rasio hargalaba (PER) mengukur seberapa banyak para investor bersedia membayar untuk rupiah dari laba yang dilaporkan” (David Wijaya, 2008).

"Price earning ratio menunjukkan rasio harga saham terhadap keuntungannya, dengan

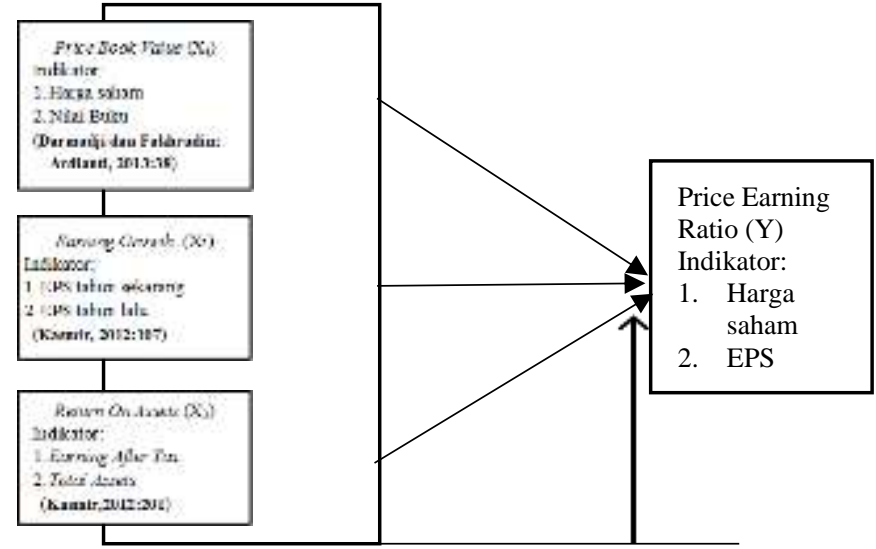

Gambar 6.

Skema Kerangka pemikiran

Sumber: Data diolah peneliti

kata lain menunjukkan berapa besar pemodal menilai harga saham terhadap kelipatan dari keuntungannya" (Purwaningrum, 2011)

Tandelilin menyatakan bahwa PER menunjukkan besarnya harga setiap satu rupiah yang harus dibayarkan investor untuk memperoleh satu rupiah earning perusahaan (Viandita, Suhadak, \& Husaini, 2013).

\section{Hipotesis}

H1: Terdapat pengaruh signifikan antara price book value terhadap price earning ratio pada perusahaan pembiayaan yang terdaftar di Bursa Efek Indonesia.

H2: Terdapat pengaruh signifikan antara earning growth terhadap price earning ratio pada perusahaan pembiayaan yang terdaftar di Bursa Efek Indonesia.

H3: Terdapat pengaruh signifikan antara return on assets terhadap price earning 
Analisis Price Book Value, Earning Growth.... (Septianty Intan KP. \& Catur Martian F.)

ratio pada perusahaan pembiayaan yang terdaftar di Bursa Efek Indonesia.

H4: Terdapat Pengaruh signifikan antara price book value, earning growth dan return on assets secara bersama-sama terhadap price earning ratio pada perusahaan pembiayaan yang terdaftar di Bursa Efek Indonesia.

\section{METODE RISET}

Metode penelitian yang digunakan adalah explanatory research dengan pendekatan kuantitatif. Penelitian yang digunakan adalah deskriptif verifikatif. Metode deskriptif digunakan untuk menggambarkan kondisi masing-masing variabel pada perusahaan manufaktur dan metode verifikatif digunakan untuk mengetahui tingkat pengaruh variabel independen terhadap variabel dependen.

Untuk itu sampel yang diambil dari populasi harus betul-betul representatif (mewakili). Teknik penarikan sampel menggunakan purposive sampling. Sampel dalam penelitian ini ditentukan berdasarkan beberapa kriteria sebagai berikut:
Tabel 1.

Kriteria Sampling

\begin{tabular}{|l|c|}
\hline $\begin{array}{l}\text { Perusahaan pembiayaan periode 2011-2016 } \\
\text { yang terdaftar di Bursa Efek Indonesia }\end{array}$ & 16 \\
\hline $\begin{array}{l}\text { Perusasahaan pembiayaan periode 2011-2016 } \\
\text { yang tidak mempublikasikan laporan } \\
\text { keuangan secara tidak lengkap }\end{array}$ & 6 \\
\hline Total sampel & 10 \\
\hline $\begin{array}{l}\text { Sampel akhir perusahaan pembiayaan } \\
\text { 2011-2016 }\end{array}$ & 60 \\
\hline Sumber: Data diolah & \\
\hline
\end{tabular}

Teknik penarikan sampel pada penelitian ini adalah nonprobability sampling yaitu purposive sampling. Sebagai pertimbangan sampel diambil berdasarkan kriteria sebagaimana tertera dalam tabel 1 .

\section{PEMBAHASAN}

\section{Analisis Price book value}

Dari hasil penelitian dapat diperoleh gambaran price book value pada perusahaan pembiayaan yang terdaftar di Bursa Efek Indonesia periode 2011-2016 sebagai berikut. 
Tabel 2.

Tingkat Price book value pada perusahaan pembiayaan yang terdaftar di BEI

\begin{tabular}{|c|c|c|c|c|c|c|c|}
\hline \multirow{2}{*}{ No } & \multirow{2}{*}{$\begin{array}{l}\text { Nama } \\
\text { Perusahaan }\end{array}$} & \multicolumn{6}{|c|}{ Tahun } \\
\hline & & 2011 & 2012 & 2013 & 2014 & 2015 & 2016 \\
\hline 1 & $\begin{array}{l}\text { PT Adira } \\
\text { Dinamika } \\
\text { Multi } \\
\text { Finance } \\
\end{array}$ & 2.87 & 1.95 & 1.35 & 1.77 & 0.80 & 1.36 \\
\hline 2 & $\begin{array}{l}\text { PT Buana } \\
\text { Finance }\end{array}$ & 0.78 & 1.15 & 1.16 & 2.79 & 1.90 & 1.25 \\
\hline 3 & $\begin{array}{l}\text { PT BFI } \\
\text { Finance } \\
\text { Indonesia }\end{array}$ & 0.02 & 0.01 & 0.01 & 0.01 & 0.01 & 0.01 \\
\hline 4 & $\begin{array}{l}\text { PT Batavia } \\
\text { Prosperindo } \\
\text { Finance }\end{array}$ & 1.31 & 0.96 & 1.90 & 1.59 & 1.63 & 1.35 \\
\hline 5 & $\begin{array}{l}\text { PT Clipan } \\
\text { Finance } \\
\text { Indonesia }\end{array}$ & 0.75 & 0.62 & 0.55 & 0.54 & 0.30 & 0.25 \\
\hline 6 & $\begin{array}{l}\text { PT Dana } \\
\text { Supra } \\
\text { Erapacific }\end{array}$ & 0.88 & 1.52 & 1.71 & 1.67 & 0.19 & 0.88 \\
\hline 7 & $\begin{array}{l}\text { PT Radana } \\
\text { Bhaskara } \\
\text { Finance }\end{array}$ & 1.70 & 1.63 & 1.33 & 1.04 & 0.85 & 1.14 \\
\hline 8 & $\begin{array}{l}\text { PT Tifa } \\
\text { Finance }\end{array}$ & 1.05 & 1.08 & 1.24 & 0.84 & 0.51 & 0.53 \\
\hline 9 & $\begin{array}{l}\text { PT Trust } \\
\text { Finance } \\
\text { Indonesia }\end{array}$ & 1.90 & 1.09 & 0.85 & 0.79 & 0.71 & 0.65 \\
\hline 10 & $\begin{array}{l}\text { PT Verena } \\
\text { Multi } \\
\text { Finance }\end{array}$ & 0.70 & 0.47 & 0.36 & 0.29 & 0.56 & 0.52 \\
\hline & Maksimum & 2.87 & 1.95 & 1.90 & 2.79 & 1.90 & 1.36 \\
\hline & Minimum & 0.02 & 0.01 & 0.01 & 0.01 & 0.01 & 0.01 \\
\hline & Rata-rata & 1.20 & 1.05 & 1.05 & 1.13 & 0.75 & 0.79 \\
\hline
\end{tabular}

Sumber: Data diolah

Berdasarkan tabel 2, dapat dilihat bahwa price book value pada sepuluh perusahaan pembiayaan yang terdaftar di Bursa Efek Indonesia periode 2011-2016 berfluktuatif.

Price book value tertinggi tahun 2011 mencapai 2.87 kali pada PT Adira Dinamika Multi Finance, tahun 2012 mencapai 1.95 kali pada PT Adira Dinamika Multi Finance, tahun 2013 mencapai 1.90 kali pada PT Batavia Prosperindo Finance, tahun 2014 mencapai 2.79 kali pada PT Buana Finance, tahun 2015 mencapai 1.90 kali pada PT Buana Finance dan tahun 2016 mencapai 1.36 kali pada PT Adira Dinamika Multi Finance. Tingginya tingkat price book value disebabkan oleh nilai buku yang dimiliki perusahaan tinggi. Penyebab tingginya nilai buku adalah jumlah ekuitas lebih besar dari jumlah saham yang beredar di perusahaan.

Price book value terendah pada perusahaan pembiayaan yang terdaftar di Bursa Efek Indonesia periode 2011-2016 dimiliki oleh PT BFI Finance Indonesia dari tahun 2011 sebesar 0.02 kali, dan tahun 2012 sampai 2016 sebesar 0.01 kali. Penyebab rendahnya PBV yaitu nilai buku perusahaannya rendah. Nilai buku perusahaan rendah disebabkan oleh jumlah ekuitas lebih kecil dari jumlah saham yang beredar.

Rata-rata price book value pada perusahaan pembiayaan yang terdaftar di bursa efek Indonesia periode 2011-2016 mengalami fluktuasi, tahun 2011 sebesar 1.20 kali, tahun 2012 sebesar 1.05 kali, tahun 2013 sebesar 1.05 kali, tahun 2014 sebesar 2.79 kali, tahun 2015 sebesar 1.90 kali dan tahun 2016 sebesar 1.36 kali. Dapat diketahui rata-rata price book value pada perusahaan pembiayaan periode 2011- 
Tabel 3.

Tingkat Earning growth pada perusahaan pembiayaan yang terdaftar di BEI

\begin{tabular}{|c|c|c|c|c|c|c|c|}
\hline \multirow{2}{*}{ No } & \multirow{2}{*}{$\begin{array}{c}\text { Nama } \\
\text { Perusahaan } \\
\end{array}$} & \multicolumn{6}{|c|}{ Tahun } \\
\hline & & 2011 & 2012 & 2013 & 2014 & 2015 & 2016 \\
\hline 1 & $\begin{array}{l}\text { PT Adira } \\
\text { Dinamika } \\
\text { Multi } \\
\text { Finance }\end{array}$ & 8 & -10 & 16 & -54 & -16 & 52 \\
\hline 2 & $\begin{array}{l}\text { PT Buana } \\
\text { Finance }\end{array}$ & 68 & 30 & -10 & -18 & -44 & -14 \\
\hline 3 & $\begin{array}{l}\text { PT } \quad \text { BFI } \\
\text { Finance } \\
\text { Indonesia }\end{array}$ & 18 & -42 & 3 & 16 & 18 & 10 \\
\hline 4 & $\begin{array}{l}\text { PT Batavia } \\
\text { Prosperindo } \\
\text { Finance } \\
\end{array}$ & -10 & 26 & 24 & -17 & 2 & -18 \\
\hline 5 & $\begin{array}{l}\text { PT Clipan } \\
\text { Finance } \\
\text { Indonesia }\end{array}$ & -5 & 20 & 15 & -2 & -28 & 82 \\
\hline 6 & $\begin{array}{l}\text { PT Dana } \\
\text { Supra } \\
\text { Erapacific }\end{array}$ & 11 & -6 & 14 & 135 & -86 & 42 \\
\hline 7 & $\begin{array}{l}\text { PT Radana } \\
\text { Bhaskara } \\
\text { Finance }\end{array}$ & 14 & -29 & 14 & 124 & -32 & -36 \\
\hline 8 & $\begin{array}{ll}\text { PT } & \text { Tifa } \\
\text { Finance } & \end{array}$ & 32 & 10 & -49 & 64 & -46 & -10 \\
\hline 9 & $\begin{array}{l}\text { PT Trust } \\
\text { Finance } \\
\text { Indonesia }\end{array}$ & 15 & 2 & -27 & -35 & -53 & 12 \\
\hline 10 & $\begin{array}{l}\text { PT Verena } \\
\text { Multi } \\
\text { Finance }\end{array}$ & -5 & 34 & 4 & -30 & 0 & -73 \\
\hline & Rata-rata & 14 & 3 & 1 & 18 & -28 & 5 \\
\hline & Maksimum & 68 & 34 & 24 & 135 & 18 & 82 \\
\hline & Minimum & -10 & -42 & -49 & -54 & -86 & -73 \\
\hline
\end{tabular}

Sumber: Data diolah

2016 dianggap sudah cukup baik karena sama dengan rata-rata industri standar sebesar 1 kali.

\section{Analisis Variabel Earning growth}

Dari hasil penelitian ini, diperoleh gambaran earning growth pada perusahaan pembiayaan yang terdaftar di Bursa Efek Indonesia periode 2011-2016 yaitu sebagaimana tertera dalam tabel 3 .

Berdasarkan tabel 3, dapat dilihat earning growth pada sepuluh perusahaan pembiayaan yang terdaftar di Bursa Efek
Indonesia periode 2011-2016 berfluktuatif. Earning growth tertinggi tahun 2011 mencapai 68\% pada PT Buana Finance, tahun 2012 mencapai 34\% pada PT Verena Multi Finance, tahun 2013 mencapai 24\% pada PT Batavia Prosperindo Finance, tahun 2014 mencapai 135\% pada PT Dana Supra Erapacific, tahun 2015 mencapai 18\% pada PT BFI Finance Indonesia dan tahun 2016 mencapai $82 \%$ pada PT Clipan Finance Indonesia.

Earning growth terendah pada perusahaan pembiayaan yang terdaftar di Bursa Efek Indonesia periode 2011-2016 dimiliki oleh PT Batavia Prosperindo dari tahun 2011 sebesar $-10 \%$, tahun 2012 sebesar $-42 \%$ pada PT BFI Finance Indonesia, tahun 2013 sebesar $-49 \%$ pada PT Tifa Finance, tahun 2014 sebesar -54\% pada PT Adira Dinamika Multi Finance, tahun 2015 sebesar -86\% pada PT Dana Supra Erapacific, dan tahun 2016 sebesar $-73 \%$ pada PT Trust Finance Indonesia.

Rata-rata earning growth pada perusahaan pembiayaan yang terdaftar di Bursa Efek Indonesia periode 2011-2016 mengalami fluktuasi. Fluktuasi yang terjadi pada tahun 2011 sebesar 14\%, tahun 2012 sebesar 3\%, tahun 2013 sebesar 1\%, tahun 2014 sebesar 8\%, tahun 2015 sebesar -28\% dan tahun 2016 
Tabel 4.

Tingkat Return on assets pada perusahaan pembiayaan yang terdaftar di BEI

\begin{tabular}{|l|l|c|c|c|c|c|c|}
\hline \multirow{2}{*}{ No } & $\begin{array}{l}\text { Nama } \\
\text { Perusahaan }\end{array}$ & 2011 & 2012 & 2013 & 2014 & 2015 & 2016 \\
\hline & $\begin{array}{l}\text { PT Adira } \\
\text { Dinamika } \\
\text { Multi } \\
\text { Finance }\end{array}$ & 9.37 & 5.57 & 5.51 & 2.65 & 2.4 & 3.65 \\
\hline 2 & $\begin{array}{l}\text { PT Buana } \\
\text { Finance }\end{array}$ & 3.54 & 4.3 & 3.6 & 3.09 & 1.96 & 1.47 \\
\hline 3 & $\begin{array}{l}\text { PT BFI } \\
\text { Finance } \\
\text { Indonesia }\end{array}$ & 8.02 & 7.46 & 6.13 & 6.17 & 5.52 & 6.4 \\
\hline 4 & $\begin{array}{l}\text { PT Batavia } \\
\text { Prosperindo }\end{array}$ & 6,32 & 5.53 & 4.54 & 3.82 & 4.22 & 3.27 \\
\hline Finance & $\begin{array}{l}\text { PT Clipan } \\
\text { Finance } \\
\text { Indonesia }\end{array}$ & 5.77 & 6.85 & 6.3 & 5.99 & 4.31 & 3.05 \\
\hline 6 & $\begin{array}{l}\text { PT Dana } \\
\text { Supra } \\
\text { Erapacific }\end{array}$ & 4.37 & 3.72 & 4.1 & 8.79 & 1.2 & 14.49 \\
\hline 7 & $\begin{array}{l}\text { PT Radana } \\
\text { Bhaskara } \\
\text { Finance }\end{array}$ & 1.7 & 0.95 & 0.92 & 1.51 & 1.29 & 0.71 \\
\hline 8 & $\begin{array}{l}\text { PT Tifa } \\
\text { Finance }\end{array}$ & 3.88 & 3.99 & 3.06 & 3.36 & 1.49 & 1.25 \\
\hline 9 & $\begin{array}{l}\text { PT Trust } \\
\text { Finance } \\
\text { Indonesia }\end{array}$ & 5.34 & 5.13 & 4.67 & 3.8 & 3.28 & 3.97 \\
\hline 10 & $\begin{array}{l}\text { PT Verena } \\
\text { Multi } \\
\text { Finance }\end{array}$ & 1.62 & 1.69 & 1.65 & 1.12 & 0.13 & 0.36 \\
\hline & Maksimum & 9.37 & 7.46 & 6.3 & 8.79 & 5.52 & 14.49 \\
\hline Minimum & 1.62 & 0.95 & 0.92 & 1.12 & 0.13 & 0.36 \\
\hline & Rata-rata & 4.99 & 4.52 & 4.05 & 4.03 & 2.58 & 3.86 \\
\hline
\end{tabular}

Sumber: Data diolah

sebesar 5\%. Dapat diketahui rata-rata earning growth pada perusahaan pembiayaan periode 2011-2016 dianggap sudah cukup baik karena sudah sesuai standar industri.

\section{Analisa Return on assets}

Dari hasil penelitian, diperoleh gambaran return on assets pada perusahaan pembiayaan yang terdaftar di Bursa Efek Indonesia periode 2011-2016 sebagaimana tertera dalam tabel 4 .
Berdasarkan tabel 4, dapat dilihat return on assets pada sepuluh perusahaan pembiayaan yang terdaftar di Bursa Efek Indonesia periode 2011-2016 berfluktuatif. Return on assets tertinggi tahun 2011 mencapai 9,37\% pada PT Adira Dinamika Multi Finance, tahun 2012 mencapai $7,46 \%$ pada PT BFI Finance Indonesia, tahun 2013 mencapai 6,30\% pada PT Clipan Finance Indonesia, tahun 2014 mencapai 8,79\% pada PT Dana Supra Erapacific, tahun 2015 mencapai 5,52\% pada PT BFI Finance Indonesia dan tahun 2016 mencapai 14,49\% pada PT Dana Supra Erapacific.

Return on assets terendah tahun 2011 sebesar 1,62\% pada PT Verena Multi Finance, tahun 2012 sebesar 0,95\% pada PT Radana Bhaskara Finance, tahun 2013 sebesar 0,92\% pada PT Radana Bhaskara Finance, tahun 2014 sebesar 1,12\% pada PT Verena Multi Finance, tahun 2015 sebesar $0,13 \%$ pada PT Verena Multi Finance, dan tahun 2016 sebesar 0,36\% pada PT Verena Multi Finance.

Rata-rata return on assets pada perusahaan pembiayaan yang terdaftar di bursa efek Indonesia periode 2011-2016 mengalami fluktuasi, yaitu pada tahun 2011 sebesar 4,99\%, tahun 2012 sebesar 4,52\%, tahun 2013 sebesar 4,05\%, tahun 2014 sebesar 4,03\%, tahun 2015 
sebesar 2,58\% dan tahun 2016 sebesar 3,86\%.

Dapat diketahui rata-rata return on assets pada perusahaan pembiayaan periode 2011-2016 sebesar dianggap sudah cukup baik karena sama dengan standar industri.

\section{Analisis Variabel Price earning ratio}

Berdasarkan hasil penelitian dapat diperoleh gambaran price earning ratio pada perusahaan pembiayaan yang terdaftar di Bursa Efek Indonesia periode 2011-2016 sebagaimana tertera dalam tabel 5 .

Berdasarkan tabel 5. dapat dilihat price earning ratio pada sepuluh perusahaan pembiayaan yang terdaftar di Bursa Efek Indonesia periode 2011-2016 berfluktuasi. Price earning ratio tertinggi tahun 2011 mencapai 21,19 kali pada PT Dana Supra Erapacific, tahun 2012 mencapai 40,37 kali pada PT Dana Supra Erapacific, tahun 2013 mencapai 41,27 kali pada PT Dana Supra Erapacific, tahun 2014 mencapai 27,84 kali pada PT Buana Finance, tahun 2015 mencapai 33,19 kali pada PT Verena Multi Finance dan tahun 2016 mencapai 59,63 kali pada PT Dana Supra Erapacific.

Price earning ratio terendah tahun 2011 sebesar 5,24 kali pada PT Verena Multi
Tabel 5.

Tingkat price earning ratio pada perusahaan pembiayaan yang terdaftar di BEI

\begin{tabular}{|c|l|c|c|c|c|c|c|}
\hline \multirow{2}{*}{ No } & $\begin{array}{l}\text { Nama } \\
\text { Perusahaan }\end{array}$ & 2011 & 2012 & 2013 & 2014 & 2015 & 2016 \\
\hline \multirow{2}{*}{1} & $\begin{array}{l}\text { PT Adira } \\
\text { Dinamika } \\
\text { Multi } \\
\text { Finance }\end{array}$ & 8.02 & 6.91 & 4.74 & 9.09 & 5.22 & 6.69 \\
\hline 2 & $\begin{array}{l}\text { PT Buana } \\
\text { Finance }\end{array}$ & 7.24 & 7.78 & 9.46 & 27.84 & 33.19 & 25.72 \\
\hline 3 & $\begin{array}{l}\text { PT BFI } \\
\text { Finance } \\
\text { Indonesia }\end{array}$ & 10.19 & 6.28 & 7.50 & 6.52 & 6.15 & 7.00 \\
\hline 4 & $\begin{array}{l}\text { PT Batavia } \\
\text { Prosperindo } \\
\text { Finance }\end{array}$ & 9.24 & 6.15 & 11.58 & 18.36 & 19.71 & 20.06 \\
\hline 5 & $\begin{array}{l}\text { PT Clipan } \\
\text { Finance } \\
\text { Indonesia }\end{array}$ & 5.88 & 4.60 & 3.94 & 4.40 & 3.83 & 4.66 \\
\hline 6 & $\begin{array}{l}\text { PT Dana } \\
\text { Supra } \\
\text { Erapacific }\end{array}$ & 21.19 & 40.37 & 41.27 & 18.76 & 15.20 & 59.63 \\
\hline 7 & $\begin{array}{l}\text { PT Radana } \\
\text { Bhaskara } \\
\text { Finance }\end{array}$ & 19.37 & 27.69 & 21.08 & 8.40 & 10.64 & 22.91 \\
\hline 8 & $\begin{array}{l}\text { PT Tifa } \\
\text { Finance }\end{array}$ & 5.49 & 5.98 & 11.46 & 6.60 & 7.68 & 9.20 \\
\hline 9 & $\begin{array}{l}\text { PT Trust } \\
\text { Finance } \\
\text { Indonesia }\end{array}$ & 14.87 & 9.46 & 11.10 & 16.63 & 16.68 & 14.43 \\
\hline 10 & $\begin{array}{l}\text { PT Verena } \\
\text { Multi } \\
\text { Finance }\end{array}$ & 5.24 & 3.09 & 2.67 & 3.33 & 6.58 & 23.10 \\
\hline & Maksimum & 21.19 & 40.37 & 41.27 & 27.84 & 33.19 & 59.63 \\
\hline & Minimum & 5.24 & 3.09 & 2.67 & 3.33 & 3.83 & 4.66 \\
\hline & Rata-rata & 10.67 & 11.83 & 12.48 & 11.99 & 12.49 & 19.34 \\
\hline & & & & & & & \\
\hline
\end{tabular}

Sumber: Data Diolah

Finance, tahun 2012 sebesar 3,09 kali pada PT Verena Multi Finance, tahun 2013 sebesar 2,67 kali pada PT Verena Multi Finance, tahun 2014 sebesar 3,33 kali pada PT Verena Multi Finance, tahun 2015 sebesar 3,83 kali pada PT Clipan Finance Indonesia, tahun 2016 sebesar 4,66 kali pada PT Clipan Finance Indonesia.

Rata-rata price earning ratio pada perusahaan pembiayaan yang terdaftar di bursa 
Efek Indonesia periode 2011-2016 cenderung meningkat, yaitu pada tahun 2011 sebesar 10,67 kali, tahun 2012 sebesar 11,83 kali, tahun 2013 sebesar 12,48 kali, tahun 2014 sebesar 11,99 kali, tahun 2015 sebesar 12,49 kali dan tahun 2016 sebesar 19,34 kali. Dapat diketahui ratarata price earning ratio pada perusahaan pembiayaan periode 2011-2016 sebesar dianggap sudah cukup baik karena sama dengan rata-rata industri.

\section{Analisis Regresi Berganda}

Dalam penelitian ini analisis regresi berganda digunakan karena variabel yang menjadi kajian dalam penelitian terdiri dari tiga variabel independen yaitu price book value sebagai $\mathrm{X}_{1}$, earning growth sebagai $\mathrm{X}_{2}$, return on assets sebagai $\mathrm{X}_{3}$ dan satu variabel dependen yaitu price earning ratio. Hasil perhitungannya dapat dilihat pada tabel 6 .

Berdasarkan hasil analisis regresi berganda yang diperoleh dari tabel 6, didapatkan hasil perolehan persamaan regresi berganda sebagai berikut:

$$
\begin{aligned}
& Y=1.706+0,529 X_{1}+(- \\
& \left.0,004 X_{2}\right)+0,022 X_{3}+\varepsilon
\end{aligned}
$$

Tabel 6.

\begin{tabular}{|c|c|c|c|c|c|c|c|}
\hline \multirow[t]{2}{*}{ Model } & \multicolumn{2}{|c|}{ 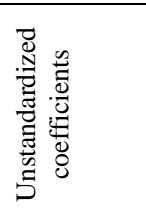 } & \multirow{2}{*}{ 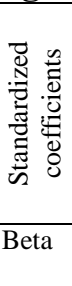 } & \multirow[t]{2}{*}{$\mathrm{t}$} & \multirow[t]{2}{*}{ Sig } & \multicolumn{2}{|c|}{ 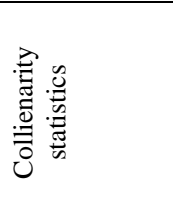 } \\
\hline & B & $\begin{array}{l}\text { Std. } \\
\text { error }\end{array}$ & & & & $\begin{array}{l}\text { toler } \\
\text { ance }\end{array}$ & VIF \\
\hline 1 (constant) & $\begin{array}{l}1.7 \\
05\end{array}$ & .197 & & $\begin{array}{l}8.6 \\
42\end{array}$ & .000 & & \\
\hline $\begin{array}{l}\text { Price book } \\
\text { value }\end{array}$ & $\begin{array}{l}.52 \\
9\end{array}$ & .124 & .487 & $\begin{array}{l}4.2 \\
64\end{array}$ & .000 & .998 & 1.002 \\
\hline $\begin{array}{l}\text { Earning } \\
\text { growth }\end{array}$ & $\begin{array}{l}.00 \\
4\end{array}$ & .002 & .224 & $\begin{array}{l}- \\
1.8 \\
49\end{array}$ & .070 & .888 & 1.126 \\
\hline $\begin{array}{l}\begin{array}{l}\text { Return on } \\
\text { assets }\end{array} \\
\end{array}$ & $\begin{array}{l}.02 \\
2\end{array}$ & .033 & .081 & $\begin{array}{l}.67 \\
3\end{array}$ & .504 & .890 & 1.124 \\
\hline
\end{tabular}

Hasil Analisis Regresi Berganda

Sumber: Output SPSS

Koefisien yang terdapat pada persamaan tersebut mengandung arti sebagai berikut:

1. Nilai konstanta sebesar 1,706 menunjukkan apabila ketiga variabel independen bersifat konstan maka terjadi kenaikan nilai price earning ratio sebesar 1,706.

2. Price book value $\left(\mathrm{X}_{1}\right)$ memiliki nilai koefisien 0,529 artinya jika variabel $\mathrm{X}_{1}$ naik 1 satuan dengan asumsi price book value dianggap tetap, maka price earning ratio akan mengalami kenaikan sebesar 0,529.

3. Earning growth $\left(\mathrm{X}_{2}\right)$ memiliki nilai koefisien $-0,004$ artinya jika variabel $\mathrm{X}_{2}$ naik 1 satuan dengan asumsi earning growth dianggap tetap, maka price earning ratio akan menurun sebesar 0,004 .

4. Return on assets $\left(\mathrm{X}_{3}\right)$ memilki nilai koefisien 0,022 artinya jika variabel $\mathrm{X}_{3}$ naik 1 satuan 
dengan asumsi return on assets dianggap tetap, maka price earning ratio akan mengalami kenaikan sebesar 0,022.

\section{Analisis Korelasi Berganda}

Koefisien kolerasi digunakan untuk mengukur kekuatan hubungan antara variabel independen dengan variabel dependen. Hasil perhitungannya dapat dilihat pada tabel 7 .

Berdasarkan tabel 7, dapat dijelaskan bahwa keeratan antara variabel independen dengan variabel dependen adalah sebagai berikut:

1. Hubungan antara price book value dengan price earning ratio adalah sebesar 0,392 memiliki korelasi rendah dengan arah positif (berbanding lurus), artinya ketika price book value diprediksi meningkat maka price earning ratio pun akan meningkat.

2. Hubungan antara earning growth dengan price earning ratio adalah sebesar $-0,104$ memiliki korelasi sangat rendah dengan arah negatif (berlawanan arah), artinya ketika earning growth diprediksi meningkat maka price earning ratio menurun dan sebaliknya.

3. Hubungan antara return on assets dengan price earning ratio adalah sebesar 0,136 memiliki korelasi sangat rendah dengan arah positif (berbanding lurus), artinya ketika
Tabel 7.

Hasil Output Koefisien Kolerasi

\begin{tabular}{|c|c|c|c|c|c|}
\hline & & $\begin{array}{l}\text { Price } \\
\text { earning } \\
\text { ratio }\end{array}$ & $\begin{array}{l}\text { Price } \\
\text { book } \\
\text { value }\end{array}$ & $\begin{array}{l}\text { Earning } \\
\text { growth }\end{array}$ & $\begin{array}{l}\text { Return } \\
\text { on } \\
\text { assets }\end{array}$ \\
\hline \multirow[t]{4}{*}{$\begin{array}{l}\text { Pearson } \\
\text { correlation }\end{array}$} & $\begin{array}{l}\text { Price } \\
\text { earning } \\
\text { ratio }\end{array}$ & 1.000 & .392 & -.104 & .136 \\
\hline & $\begin{array}{l}\text { Price } \\
\text { book } \\
\text { value }\end{array}$ & .392 & 1.000 & .047 & .019 \\
\hline & $\begin{array}{l}\text { Earning } \\
\text { growth }\end{array}$ & -.104 & .047 & 1.000 & .332 \\
\hline & $\begin{array}{l}\text { Return } \\
\text { on } \\
\text { assets }\end{array}$ & .136 & .019 & .332 & 1.000 \\
\hline \multirow[t]{4}{*}{$\begin{array}{l}\text { Sig } \\
\text { tailed) }\end{array}$} & $\begin{array}{l}\text { Price } \\
\text { earning } \\
\text { ratio }\end{array}$ & . & .001 & .215 & .150 \\
\hline & $\begin{array}{l}\text { Price } \\
\text { book } \\
\text { value }\end{array}$ & .001 & . & .360 & .444 \\
\hline & $\begin{array}{l}\text { Earning } \\
\text { growth }\end{array}$ & .215 & .360 & . & .005 \\
\hline & $\begin{array}{l}\text { Return } \\
\text { on } \\
\text { assets }\end{array}$ & .150 & .444 & .005 & . \\
\hline \multirow[t]{4}{*}{$N$} & $\begin{array}{l}\text { Price } \\
\text { earning } \\
\text { ratio }\end{array}$ & 60 & 60 & 60 & 60 \\
\hline & $\begin{array}{l}\text { Price } \\
\text { book } \\
\text { value }\end{array}$ & 60 & 60 & 60 & 60 \\
\hline & $\begin{array}{l}\text { Earning } \\
\text { growth }\end{array}$ & 60 & 60 & 60 & 60 \\
\hline & $\begin{array}{l}\text { Return } \\
\text { on } \\
\text { assets }\end{array}$ & 60 & 60 & 60 & 60 \\
\hline
\end{tabular}

Sumber: Output SPSS

return on assets diprediksi meningkat maka

price earning ratio pun akan meningkat.

\section{Koefisien Determinasi}

Nilai koefisien determinasi diperoleh berdasarkan hasil korelasi antar variabel dan perhitungan menggunakan SPSS 23. Besar pengaruh secara simultan hasil koefisien determinasi dapat dilihat pada tabel 8 . 
Tabel 8.

Hasil Output Koefisien Determinasi

\begin{tabular}{|c|c|c|c|c|c|}
\hline Model & $\mathrm{R}$ & $\begin{array}{c}\mathrm{R} \\
\text { Square }\end{array}$ & $\begin{array}{c}\text { Adjusted } \\
\mathrm{R} \\
\text { Square }\end{array}$ & $\begin{array}{c}\text { Std. } \\
\text { Error of } \\
\text { the } \\
\text { Estimate }\end{array}$ & $\begin{array}{c}\text { Durbin } \\
\text { Watson }\end{array}$ \\
\hline 1 & .522 & .272 & .233 & .62024 & 1.658 \\
\hline
\end{tabular}

Sumber: Data Diolah

Berdasarkan tabel 8, diperoleh $\mathrm{R}$ square sebesar 0,272, ini berarti price book value, earning growth dan return on assets secara bersama-sama mempengaruhi price earning ratio sebesar 0,272 atau $27 \%$. Kesimpulannya, $27 \%$ price book value, earning growth dan return on assets mempengaruhi price earning ratio perusahaan pembiayaan yang terdaftar di bursa Efek Indonesia periode 2011-2016 dan 73\% sisanya dipengaruhi oleh variabel lain atau faktor lain di luar penelitian.

\section{Pengujian Hipotesis}

\section{Pengujian Hipotesis Secara Parsial}

Berdasarkan hasil dan perhitungan statistik uji t yang telah diperoleh, variabel price book value memiliki nilai $t_{\text {hitung }}$ lebih besar dari $t_{\text {tabel }}(4,264>2,002)$ dengan nilai signifikansi $0,000<0.05$. Dengan demikian Ha diterima dan Ho ditolak yang berarti price book value secara parsial berpengaruh signifikan terhadap price earning ratio.

Berdasarkan hasil dan perhitungan statistik uji t yang telah diperoleh, variabel
Tabel 9.

Hasil Uji t

\begin{tabular}{|c|c|c|c|c|c|c|c|}
\hline \multirow[t]{2}{*}{ Model } & \multicolumn{2}{|c|}{ 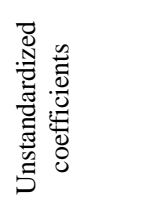 } & \multirow{2}{*}{ 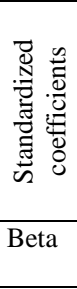 } & \multirow[t]{2}{*}{$\mathrm{t}$} & \multirow[t]{2}{*}{ Sig } & \multicolumn{2}{|c|}{ 莺 } \\
\hline & B & $\begin{array}{l}\text { Std. } \\
\text { error }\end{array}$ & & & & $\begin{array}{l}\text { toler } \\
\text { ance }\end{array}$ & VIF \\
\hline 1 (constant) & $\begin{array}{l}1.7 \\
05 \\
\end{array}$ & .197 & & $\begin{array}{l}8.6 \\
42 \\
\end{array}$ & .000 & & \\
\hline $\begin{array}{l}\text { Price book } \\
\text { value }\end{array}$ & $\begin{array}{l}.52 \\
9\end{array}$ & .124 & .487 & $\begin{array}{l}4.2 \\
64\end{array}$ & .000 & .998 & 1.002 \\
\hline $\begin{array}{l}\text { Earning } \\
\text { growth }\end{array}$ & $\begin{array}{l}.00 \\
4\end{array}$ & .002 & .224 & $\begin{array}{l}- \\
1.8 \\
49\end{array}$ & .070 & .888 & 1.126 \\
\hline $\begin{array}{l}\text { Return on } \\
\text { assets }\end{array}$ & $\begin{array}{l}.02 \\
2 \\
\end{array}$ & .033 & .081 & $\begin{array}{l}.67 \\
3 \\
\end{array}$ & .504 & .890 & 1.124 \\
\hline
\end{tabular}

Sumber: Data Diolah

earning growth memiliki $t_{\text {hitung }}$ lebih kecil dari $t_{\text {tabel }}(-1,849<2,002)$ dengan nilai signifikansi 0,070>0.05. Dengan demikian, Ha ditolak dan Ho diterima yang berarti variabel ini tidak berpengaruh signifikan terhadap price earning ratio.

Berdasarkan hasil dan perhitungan statistik uji t yang telah diperoleh, variabel return on assets $\mathrm{t}_{\text {hitung }}$ lebih kecil dari $\mathrm{t}_{\text {tabel }}$ $(0,673<2,002)$ dengan nilai signifikansi 0,504>0.05. Hal ini menunjukkan bahwa Ha ditolak dan Ho diterima yang berarti variabel ini tidak berpengaruh signifikan terhadap price earning ratio. 
Tabel 10.

\section{Hasil Uji F}

\begin{tabular}{|c|c|c|c|c|c|c|}
\hline & Model & $\begin{array}{c}\text { Sum of } \\
\text { Squares }\end{array}$ & df & $\begin{array}{c}\text { Mean } \\
\text { Square }\end{array}$ & F & Sig. \\
\hline 1 & Regression & 8.068 & 3 & 2.689 & 6.990 & .000 \\
\hline & Residual & 21.543 & 56 & .385 & & \\
\hline & Total & 29.611 & 59 & & & \\
\hline
\end{tabular}

Sumber: Output SPSS

\section{Pengujian Hipotesis Secara Simultan}

Dari hasil pengolahan data, diperoleh $F_{\text {hitung }}$ sebesar 6,990 dan $F_{\text {tabel }}$ sebesar 2,77. Karena nilai $F_{\text {hitung }}$ lebih besar dari $F_{\text {tabel }}$ $(6,990>2,77)$ dengan nilai signifikansi 0,000 jauh lebih kecil dari 0,05, maka Ha diterima dan Ho ditolak yang berarti price book value, earning growth dan return on assets secara simultan berpengaruh signifikan terhadap price earning ratio.

\section{|KESIMPULAN DAN SARAN}

\section{Kesimpulan}

Berdasarkan hasil penelitian dan pembahasan pada bab sebelumnya mengenai pengaruh price book value, earning growth dan return on assets terhadap price earning ratio pada perusahaan pembiayaan periode 20112016 yang terdaftar di Bursa Efek Indonesia, maka penulis membuat kesimpulan sebagai berikut:

1. Rata-rata untuk price book value pada perusahaan pembiayaan cukup baik.
2. Rata-rata earning growth pada perusahaan pembiayaan cukup baik.

3. Rata-rata untuk return on assets pada perusahaan pembiayaan cukup baik.

4. Rata-rata untuk price earning ratio pada perusahaan pembiayaan cukup baik.

5. Hasil uji hipotesis dengan uji parsial (Uji t) menunjukkan price book value berpengaruh signifikan terhadap price earning ratio.

6. Hasil uji hipotesis dengan uji parsial (Uji t) menunjukkan earning growth berpengaruh tidak signifikan terhadap price earning ratio.

7. Hasil uji hipotesis dengan uji parsial (Uji t) menunjukkan return on assets berpengaruh tidak signifikan terhadap price earning ratio.

8. Hasil uji hipotesis dengan uji simultan (Uji F) menunjukkan price book value, earning growth dan return on assets berpengaruh signifikan terhadap price earning ratio pada perusahaan pembiayaaan.

\section{Saran}

Berdasarkan hasil penelitian dan kesimpulan yang sudah dipaparkan maka dapat diberikan saran sebagai berikut:

1. Peneliti selanjutnya dapat menambah variabel bebas yang lainnya seperti, dividend payout ratio, debt to equity ratio, return on 
investment supaya memilki pengaruh yang

lebih signifikan dalam memprediksi price earning ratio

2. Bagi perusahaan untuk menjaga loyalitas pemegang saham, sebaiknya kemampuan memperoleh laba dapat dipertahankan dan ditingkatkan dengan cara mengurangi penggunaan pinjaman jangka panjang dikarenakan bunga yang semakin meningkat setiap tahunnya. Serta penggunaan hutang perusahaan harus dipertimbangkan dengan baik agar meminimalisasi terjadinya resiko perusahaan yang gagal membayar hutang.

3. Bagi investor mempertimbangkan rasio keuangan lainnya agar dapat mengambil keputuisan yang tepat dalam berinvestasi. 
Analisis Price Book Value, Earning Growth.... (Septianty Intan KP. \& Catur Martian F.)

\section{DAFTAR PUSTAKA}

Agus, Martowardojo D.W. 2017. Kajian Stabilitas keuangan. Jakarta: Bank Indonesia. www.bi.go.id (5 April 2017)

Agus, Martowardojo D.W. 2017. Laporan Pelaksanaan Tugas dan Wewenang Bank Indonesia. www.bi.go.id (5 April 2017).

Aji, M. N., \& Irene Rini Demi Pangestuti. (2012). Analisis Faktor-faktor Yang Mempengaruhi Price Earning Ratio ( Studi Empiris Pada Perusahaan Manufaktur yang Terdaftar di Bursa Efek Indonesia Tahun 2007-2010 ). Diponegoro Journal of Management, 1(1), 382-391.

Ardianti, Siti Hani. 2013. Pengaruh Earning Per Share, Net Profit Margin, Debt To Equity Ratio, Price book value Terhadap Return Saham (Pada Perusahaan Sub Sektor Real Estate And Property yang listing di BEI khususnya PT lippo Karawaci Tbk selama periode 2008-2012) repsitory.widyatama.ac.id (15 Mei 2017)

Arisona, V. F. (2013). Faktor-faktor yang mempengaruhi Price Earning Ratio pada Indeks LQ 45 di Bursa Efek Indonesia. Jurnal Ilmu Manajemen, 1(1), 103-112.

Carlo, M. A. (2014). Pengaruh return on equity, dividend payout ratio, dan price to earnings ratio pada return saham. E-Jurnal Akuntansi, 1, 151-164. http://doi.org/10.1017/CBO9781107415324.004

David Wijaya. (2008). Pengaruh Rasio Modal Saham Terhadap Return Saham Perusahaan-Perusahaan Telekomunikasi Go Public di Indonesia Periode 2007. Jurnal Manajemen Dan Kewirausahaan, 10(2), $\quad$ pp.136-152. $\quad$ Retrieved from http://puslit2.petra.ac.id/ejournal/index.php/man/article/view/17040

Fahmi, Irham. 2012. Kinerja Keuangan. Bandung: CV Alfabeta

Fahmi, Irham. 2013. Analisis Laporan Keuangan. Bandung: CV Alfabeta

Kabajeh, M. A., AL Nu'aimat, S. M., \& Dahmash, F. N. (2012). The Relationship between the ROA, ROE and ROI Ratios with Jordanian Insurance Public Companies Market Share Prices Dr . Said Mukhled Ahmed A L Nu' aimat. International Journal of Humanities and Social Science, 2(11), $115-120$.

Kasmir. 2012. Analisis Laporan Keuangan. Jakarta: PT Raja Grafindo Persada 
Kasmir. 2015. Analisis Laporan Keuangan. Jakarta: PT Rajawali Pers

Khan, M. (2009). Price Earning Ratio and Market to Book Ratio. Munich Personal Archive, 7(39922), $0-29$.

Kurniawati, S. L. (2012). Faktor Penentu Return Saham Dengan Price To Book Value Sebagai Variabel Moderasi. Keuangan Dan Perbankan, 16(3), 382-389.

Marlina, T. (2013). Pengaruh Earning Per Share, Return On Equity, Debt To Equity Ratio dan Size Terhadap Price To Book Value. Jurnal Ilmiah Akuntansi Kesatuan, 1(1), 59-72. Retrieved from http://digilib.mercubuana.ac.id/manager/t!@file_artikel_abstrak/Isi_Artikel_715653482132.pdf

Martani, D., \& Khairurizka, R. (2009). The effect of financial ratios, firm size, and cash flow from operating activities in the interim report to the stock return. Serial Chinese Business Review, 8(6), $1537-1506$.

Purwaningrum, E. (2011). Factors Affecting Price Earning Ratio of Company's Share in the Manufacture Sector. Jurnal Ekonomi Dan Bisnis, 10(1), 47-51.

Putri, F. V., \& Widodo, A. (2016). Pengaruh ROA, DER, dan AG terhadap DPR Perusahaan Pertambangan BEI 2010-2014. Ecodemica, IV(1), 56-62.

Rasyid, A. (2015). Effects of ownership structure, capital structure, profitability and company's growth towards firm value. International Journal of Business and Management Invention

ISSN (Online, 4(4), 23198028.

Setyawati, Irma, Dwi Kartini, Sulaeman Rachman, and Erie Febrian. 2015. "Assessing the Islamic Banking Financial Performance in Indonesia." International Journal of Education and Research 3(10): 233-48. http://www.ijern.com/journal/2015/October-2015/19.pdf.

Viandita, T., Suhadak, \& Husaini, A. (2013). Pengaruh Debt Ratio ( Dr ), Price To Earning Ratio ( Per ), Earning Per Share ( Eps ), Dan Size Terhadap Harga Saham. Jurnal Administrasi Bisnis (JAB), Vol. 1(No. 2), Universitas Brawijaya, Malang.

Wijoyo, Nugroho Agung. 2016. Menakar Kinerja Perusahaan Pembiayaan JILID I. Jakarta: Universitas Indonesia. 